\title{
ТЕОРЕТИЧНІ АСПЕКТИ ДОСЛІДЖЕННЯ СУТНОСТІ АНТИКРИЗОВОГО МЕНЕДЖМЕНТУ БАНКІВСЬКИХ УСТАНОВ
}

\author{
Виктор Мельник, Ольга Колесник
}

\section{ТЕОРЕТИЧЕСКИЕ АСПЕКТЫ ИССЛЕДОВАНИЯ СИСТЕМЫ АНТИКРИЗИСНОГО МЕНЕДЖМЕНТА БАНКОВСКИХ УЧРЕЖДЕНИЙ}

\author{
Viktor Melnyk, Olga Kolesnik \\ THEORETICAL ASPECTS OF THE RESEARCH

\section{OF THE ANTI-CRISIS MANAGEMENT SYSTEM OF BANK INSTITUTIONS}

У статті розглянуто теоретичні аспекти дослідження сутності категорії «антикризовий менеджмент банку». Для цьього було використано методологію контент-аналізу для визначення наукових підходів до розуміння природи дефініиүї «антикризовий менеджмент», щуо дозволило виокремити такі концепиії трактування ичієі категорії: дискретний, проактивно-перманентний, реактивно-динамічний. Також проаналізовано сформовані в наукових роботах концепції розгляду змісту категорії «антикризовий менеджмент банку» $і$ визначено групи потениійних кризових ситуачій, які мають змогу негатвиіно впливати на діяльність банківських установ, до їх числа віднесено такі: об'єктивно-онтологічні, екзогеннодеструктивні, національно-дестабілізаційні, секторально обумовлені, ендогенно-руйнівні.

Ключові слова: банківська установа; антикризовий менеджмент; антикризовий менеджмент банку; менеджмент; криза; банківська система.

Рис.: 1. Табл.: 1. Бібл.: 16.

В статье рассмотрены теоретические аспекты исследования сущности категории «антикризисный менеджмент банка». Для этого были использованы методологию контент-анализа для определения научных подходов к пониманию природы дефиниции «антикризисный менеджмент», что позволило выделить следующие концепции трактовки данной категории: дискретный, проактивно-перманентный, реактивно-динамический. Также проанализированы сложившиеся в научных работах концепции рассмотрения содержания категории «антикризисный менеджмент банка» и определены группы потенциальных кризисных ситуаций, которые могут негатвиино влиять на деятельность банковских учреждений, в их число отнесень следуюшие: объективно-онтологические, экзогеннодеструктивные, национально дестабилизирующие, секторально обусловленные, эндогенно-разрушительные.

Ключевые слова: банковское учреждение; антикризисный менеджмент; антикризисный менеджмент банка; менеджмент; кризис; банковская система.

Рис.: 1. Табл.: 1. Библ.: 16.

Within the article, theoretical aspects of the study of the category essence "anti-crisis management of the bank" are studied. For this purpose, the content analysis methodology to identify scientific approaches to understanding the nature of the definition of "anti-crisis management" was used, that allowed to distinguish the following concepts of this category interpretation: discrete, proactive-permanent, reactive-dynamic. In addition, the concept of the content review of the category of "anti-crisis management of the bank" formed in scientific works is analyzed, and groups of potential crisis situations, which can negatively affect the activities of banking institutions, are established; the above include the following: objectiveontological, exogenous-destructive, national-destabilization, sector-specific, endogenous-destructive.

Keywords: banking institution; anti-crisis management; anti-crisis management of the bank; management; crisis; banking system.

Fig.: 1. Table: 1. References: 16.

JEL Classification: G21

Постановка проблеми. Банківська система є невід’ємною складовою розвитку національної економіки. В Україні саме банківські установи виступають основними інвесторами, кредиторами економіки держави. Саме це зумовлює необхідність здійснювати підвищений нагляд за стабільністю роботи цих установ, забезпечувати належні інституційні умови їхнього розвитку. Однак важливим також є формування стабільного середовища для функціонування банків, що реалізувати, враховуючи постійні деструкційні чинники світового та національного масштабу, складно. Особливо це $\epsilon$ актуальним для фінансового сектору Україні, де ці установи відіграють ключову роль.

Відповідно, актуалізуються питання не лише забезпечення сприятливих умов для розвитку банківських установ, але і здатність цих установ протистояти саме зовнішнім негативним впливам, які досить часто мають виключно об'єктивний характер і національні уряди можуть лише частково знизити їхній деструктивний вплив на банківську

(C) Мельник В. М., Колесник О. О., 2019 
ФІНАНСОВІ РЕСУРСИ: ПРОБЛЕМИ ФОРМУВАННЯ ТА ВИКОРИСТАННЯ

систему. Отже, забезпечення систем протидії екзогенним та ендогенними факторам впливу на рівні окремих банків також є важливою складовою формування стійкості всієї банківської системи, забезпечення іiї надійності в умовах стохастичного та нестаціонарного розвитку національних економік. Важливу роль у цьому відіграє наявність дієвої системи антикризового менеджменту в банку. Цілком влучно зауважує П. М. Чуб, що за сучасних умов, які $\epsilon$ наслідком розгортання на теренах нашої держави фінансовоекономічної кризи, гостро постали питання неефективного антикризового менеджменту, а інколи - взагалі його відсутності. Саме тому важливим $є$ зосередження уваги на антикризовому менеджменті, за допомогою якого можна передбачати, вчасно розпізнавати і успішно вирішувати найскладніші проблеми [15]. Окреслене зумовлює необхідність проведення нових теоретичних, методичних досліджень 3 метою формування прикладних аспектів підвищення ефективності функціонування такої системи.

Аналіз останніх досліджень і публікацій. Особливості організації системи антикризового менеджменту у банківських установах досліджувалися в працях вітчизняних таких учених: О. Б. Афанасьєва, В. Ю. Біляєва, В.В.Бобиль, Т. А. Васильєва, В. Я. Вовк, Я. В. Жовтанецька, М. І. Звєряков, Ю. М. Коваленко, М. А. Козоріз, Е. В. Косова, А. Я. Кузнєцова, С. В. Лєонов, В. Г. Маргасова, А. А. Мещеряков, С. А. Поліщук, Н. В. Приказюк, Б. І. Пшик, В. С. Сирота, М. В. Суганяка та їхніх закордонних колег: H. Aljuhmani, W. Fonteyne, P. Grauwe, P. Honohan, L. Ivaskeviciute, B. Lietaer, I. Macerinskienè, E. Ogawa, F. Restoy.

Виділення недосліджених частин загальної проблеми. Проте, попри численні напрацювання вчених у сфері створення ефективних систем антикризового менеджменту в банківських установах, актуальними залишаються питання поглиблення теоретичних положень іiі розвитку, визначення змісту антикризового менеджменту як цілісної системи, враховуючи трансформаційні процеси в банківській системі, які зумовлені діджиталізацією всієї фінансової сфери та, відповідно, виникненням нових типів ризиків.

Мета статті. Метою цієї статті є поглиблення теоретичних положень функціонування антикризового менеджменту банківських установ, застосування системного підходу до розгляду його сутності.

Виклад основного матеріалу. Дослідження змісту антикризового менеджменту банку та особливостей його дослідження як цілісної системи почнемо зі з'ясування сутності антикризового менеджменту як окремої економічної категорії. У науковій літературі дефініції «антикризовий менеджмент» та «антикризове управління» прийнято розглядати як синонімічні поняття. Такого підходу будемо дотримуватися і в цій статті.

Антикризове управління є особливим видом управління, оскільки $є$ важливою передумовою забезпечення стійкості функціонування окремих суб'єктів господарювання до різних чинників негативної зовнішньої та внутрішньої дії. Наявність вмонтованих у систему управління антикризових механізмів дозволяє вчасно виявити потенційні загрози і прийняти рішення щодо використання інструментів для протидії ним. Погоджуємося 3 позицією С. В. Павловського, який зауважує, що ключовим чинником результативного антикризового управління підприємствами є реалізація комплексу заходів щодо фінансування антикризових програм. Для подолання кризи потрібен індивідуальний набір інструментів фінансування, що має бути адаптований до конкретних економічних умов. У цьому зв'язку особливої актуальності набуває подальший розвиток класичних та обгрунтування новітніх технологій антикризового фінансування підприємств 3 урахуванням критерію витрат на капітал [10].

У табл. 1 наведено окремі наукові підходи до розгляду сутності категорії антикризове управління. 
Наукові концепиії розгляду сутності категорії «антикризове управління»

\begin{tabular}{|c|c|}
\hline Визначення & Джерела \\
\hline $\begin{array}{l}\text { Антикризове управління це - система управління, яка має всебіч- } \\
\text { ний характер та направлена як на попередження, так і на усунення } \\
\text { несприятливих для бізнесу явищ, з використанням наявних ресур- } \\
\text { сів та потенціалу виживання, або реалізації спеціальних процедур } \\
\text { (таких як санація, реструктуризація, банкротство, ліквідація) [8]. }\end{array}$ & $\begin{array}{l}\text { Лігоненко Л. О. Антикризове } \\
\text { управління підприємством: підруч- } \\
\text { ник. Київ: КНТЕУ, 2005. } 824 \text { с. }\end{array}$ \\
\hline $\begin{array}{l}\text { Антикризове управління банківською системою передбачає сис- } \\
\text { тему управлінських заходів та рішень щодо діагностики, попере- } \\
\text { дження, нейтралізації та подолання криз і їх причин на усіх рівнях } \\
\text { банківської системи [16]. }\end{array}$ & $\begin{array}{l}\text { Шишкіна Т. М. Сучасні проблеми } \\
\text { антикризового управління у банків- } \\
\text { ській системі. Наукові праці Кірово- } \\
\text { градського національного технічно- } \\
\text { го університету. Економічні науки. } \\
\text { 2016. Вип. 29. С. 128-134. }\end{array}$ \\
\hline
\end{tabular}

Антикризове управління - система управління, що має всебічний Барановський О. Антикризові заходи характер та направлена на попередження та усунення несприят- урядів і центральних банків зарубіжливих явищ, з використанням наявних ресурсів та потенціалу ор- них країн. Вісник Національного ганізації, або реалізації спеціальних процедур (таких, як санація, банку Украӥни. 2009. № 4. С. 8-19. банкрутство, ліквідація) [1].

Антикризове управління являє собою сукупність форм, засобів та Лачкова Л. І., Лалабєкян В. А. Антикінструментів управління, спрямованих на найбільш оперативне ризове управління комерційним банвиявлення ознак кризового стану та створення відповідних переду- ком: сутність та критерії ефективності. мов для їх вчасного подолання з метою забезпечення виживання та Економічна стратегія $i$ перспективи життєздатності окремого суб'єкта господарювання (комерційного розвитку сфери торгівлі та послуг. банку), недопущення виникнення ситуації його банкрутства [7]. $\quad$ 2013. Вип. 1(1). С. 144-148.

Антикризове управління підприємством - це система заходів пе- Тимошенко О. В., Буцька О. Ю., редкризового (превентивного) характеру, спрямованих на прове- Сафарі Ф. Х. Антикризове управдення діагностики загрози банкрутства; реактивного характеру - ління як передумова підвищення пошук шляхів виходу підприємства з кризового стану; післякри- ефективності діяльності підприємсзового характеру, що містять оцінку посткризового стану підпри- тва. Економічний аналіз. 2016. Т. 23, ємства та розробку і реалізацію дій щодо усунення підприємством № 2. С. 187-192.

негативних наслідків фінансової кризи [14, с. 190].

Антикризове управління - це фінансові відносини, що представ- Перехрест Л., Бриштіна В. Антиляють собою комплексну систему управлінських заходів щодо кризове управління як чинник діагностики, попередження, нейтралізації та подолання кризових підвищення рівня фінансової безпеявищ з метою підвищення рівня фінансової безпеки, зниження ки банків. Гроші, фінанси і кредит. наслідків ураження кризою та подальшого розвитку банку шля- 2010. С. 245-249.

хом використання всього потенціалу сучасного менеджменту [11]

Джерело: систематизовано та узагальнено авторами.

Аналіз представлених у табл. 1 наукових концепцій до розгляду сутності категорії «антикризовий менеджмент» дозволяє виокремити три підходи до ії̈ трактування, а саме:

1) дискретний - антикризовий менеджмент є реакцією на значні коливання в стабільному функціонуванні економічного об'єкта й після використання його заходів та сукупності інструментів для подолання наслідків кризових ситуацій уже не використовується керівництвом. Проте при цьому не відбувається постійний моніторинг стабільності діяльності економічного об'єкта, а здійснюються періодичні, точкові перевірки;

2) проактивно-перманентний - сутність підходу полягає в розгляді антикризового менеджменту як постійної системи заходів і інструментів, які використовуються для запобігання виникненню потенційних кризових ситуацій у функціонуванні економічних об'єктів, запровадження механізмів їх виявлення та вирішення;

3) реактивно-динамічний - сутність підходу полягає у швидкій реакції на нові виклики, що стають перед економічним об'єктом унаслідок впливу деструктивних чинників на його функціонування і виникнення кризових явищ. У межах цього підходу важливими аспектами його ефективного впровадження є швидкість прийняття рішень, 
ФІНАНСОВІ РЕСУРСИ: ПРОБЛЕМИ ФОРМУВАННЯ ТА ВИКОРИСТАННЯ

професіоналізм менеджерів щодо розробки та реалізації заходів для нормалізації діяльності економічного об'єкта. При розгляді цього підходу, акцент здійснюється на подоланні кризи як уже сформованого явища.

Таким чином, у статті антикризовий менеджмент будемо розглядати як сукупність поміркованих і взаємопов'язаних заходів, відповідних інструментів, ресурсів та іншого забезпечення для попередження виникнення кризових ситуацій або подолання наслідків в результаті їх настання, що здійснюються зовнішніми і внутрішніми інстанціями, уповноваженими проводити відповідні види управлінської діяльності в межах конкретної організаційної структури. Отже, дотримуємося саме проактивно-перманентного підходу до розгляду сутності дефініції «антикризовий менеджмент». Враховуючи окреслене, проаналізуємо зміст категорії «антикризовий менеджмент банку».

Б. І. Пшик зауважує, що антикризове управління діяльністю банком зазвичай визначається як набір відповідних методів, прийомів та управлінських дій, спрямованих на виявлення, запобігання та подолання кризових явищ та ситуацій для того, щоб у подальшому забезпечити стабільну беззбиткову діяльність банківських установ. Тому метою антикризового управління на мікрорівні $є$ досягнення фінансової стійкості окремої банківської установи, яка реалізується крізь призму наступних завдань: запобігання кризовим явищам; виведення банку з кризової ситуації, якщо не вдалося ії уникнути; відновлення роботи банку на докризовому рівні [12]. У свою чергу, В. С. Сирота пропонує таке визначення: антикризовий менеджмент банку - це комбінація форм інституційного впливу та заходів організаційного і фінансово-економічного характеру у банківській діяльності, що спрямована на раннє виявлення, попередження та подолання кризових явищ із мінімальними затратами[13, с. 30]. 3 іншого боку, М. І. Звєряков, А. М. Звєряков зазначають, що антикризовий менеджмент банку - управління, завданнями якого є створення умов для збереження фінансової стійкості та довіри до банків шляхом передбачення загроз кризових явищ, аналізу їх симптомів на мета-, макро- та мікрорівнях, розробки та впровадження ефективних дій щодо зменшення негативних наслідків кризи та використання впливу ії чинників для формування подальшої стратегії розвитку банків [4, с. 61]. С. Б. Манжос категорію «антикризовий менеджмент банку» розглядає як постійний специфічний вид управління, спрямований на запобігання можливим ускладненням у діяльності окремого банку, нейтралізацію та подолання кризових явищ, забезпечення його подальшого функціонування та розвитку шляхом вжиття адекватних управлінських рішень і ефективного використання внутрішніх ресурсів банківської установи [9, с. 17].

Враховуючи окреслені наукові підходи до розгляду сутності дефініцій «антикризовий менеджмент», «антикризовий менеджмент банку», пропонуємо розглядати антикризовий менеджмент банку як сукупність поміркованих і взаємопов'язаних заходів, відповідних інструментів, спрямованих на попередження та подолання кризової ситуації в роботі банківської установи (рис. 1).

Безпосередньо ефективність формування системи антикризового менеджменту банківських установ залежить, з одного боку, від професійних якостей менеджменту банку, його акціонерів, безпосередньо фахівців, які будуть виконувати інструкції з моніторингу фінансового стану банку, рівня його конкурентоспроможності, визначати потенційні загрози та вчасно повідомляти цю інформацію у керівництву, а з іншого - від можливостей створення та підтримування роботи такої системи. При цьому варто розуміти, що кризові ситуації можуть бути абсолютно різними й виникати в результаті дії складнопередбачуваних чинників. Саме тому запас фінансової міцності в банківській установі $\epsilon$ запорукою їі спроможності протидіяти таким кризам. 


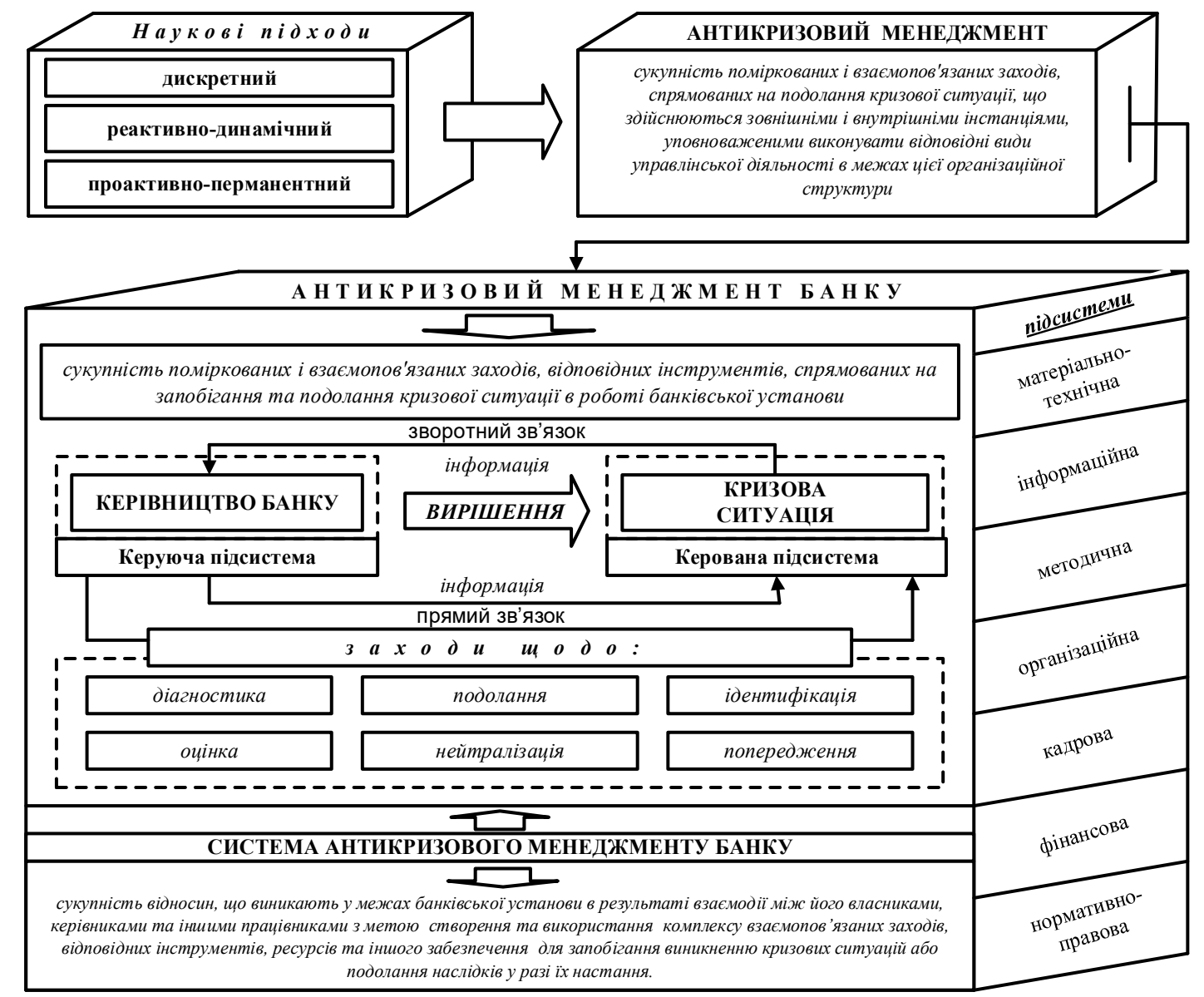

Рис. 1. Умовивід щуодо сутності категорії «антикризовий менеджмент банку» Джерело: складено авторами з урахуванням $[2 ; 3 ; 5 ; 6]$.

Фактично кризові ситуації, на наше переконання, можна систематизувати в п’ять окремих груп:

1) об'єктивно-онтологічні (притаманні системі антикризового менеджменту банку як окремому цілісному явищу, що розвивається у відповідності до загально існуючих, об'єктивних принципів системогенезу: виникнення, функціонування та руйнування);

2) екзогенно-деструктивні (обумовлені впливом зовнішніх чинників, які здійснюють вплив на велику кількість банківських систем і мають глобальні причини утворення);

3) національно-дестабілізаційні (визначаються виключно національними особливостями розвитку економіки країни, рівнем стійкості ії до впливу, насамперед, внутрішніх деструктивних чинників);

4) секторально обумовлені (виникають у межах окремих сфер національної банківської системи і відповідно впливають на функціонування всіх іiі суб'єктів, насамперед, банківських установ);

5) ендогенно-руйнівні (формуються у межах банківської установи та зумовлюються неефективним ії управлінням).

Зауважимо, що наявність такого спектру різних кризових чинників обумовлює важливе значення антикризового менеджменту, оскільки без превентивного механізму виявлення потенційних дестабілізуючих факторів, наявності можливостей їм протистояти, банківська установ стає вкрай вразливою у своїй діяльності й тим самим створює загрози для розвитку банківської системи та економіки країни. 
ФІНАНСОВІ РЕСУРСИ: ПРОБЛЕМИ ФОРМУВАННЯ ТА ВИКОРИСТАННЯ

Висновки і пропозиції. Отже, у статті розглянуто теоретичні аспекти визначення та конкретизації сутності категорії «антикризовий менеджмент банку». Для цього було розглянуто зміст дефініції «антикризовий менеджмент», проаналізовано наукові підходи до розуміння його природи. Таким чином, запропоновано антикризовий менеджмент банку розглядати як сукупність поміркованих і взаємопов'язаних заходів, відповідних інструментів, спрямованих на запобігання та подолання кризової ситуації в роботі банківської установи. Також у статті визначено основні групи кризових ситуацій, виникнення яких може негативно впливи на діяльність банківських установ, до їх числа віднесено такі: об'єктивно-онтологічні, екзогенно-деструктивні, національно-дестабілізаційні, секторально обумовлені, ендогенно-руйнівні.

Таким чином формування ефективного антикризового менеджменту у банківських установах $\epsilon$ важливою умовою формування стабільного середовища для їх розвитку й визначає рівень стійкості всієї банківської системи країни. Впровадження даного виду менеджменту в механізм управління комерційними банками повинно стати невід'ємною частиною процесу побудови дієвої системи менеджменту у таких установах.

\section{Список використаних джерел}

1. Барановський О. Антикризові заходи урядів і центральних банків зарубіжних країн. Bicник Національного банку Украӥни. 2009. № 4. С. 8-19.

2. Дубина М. В. Механізм розвитку ринку фінансових послуг на основі формування інституту довіри: теорія, методологія, практика: монографія. Чернігів: ЧНТУ, 2018. 668 с.

3. Дубина М. В., Разгуліна Н. О. Теоретичні аспекти функціонування системи банківського іпотечного кредитування фізичних осіб в Україні. Проблеми і перспективи економіки та управління. 2018. № 4 (16). С. 176-187.

4. Звєряков М. І., Звєряков А. М. Антикризове управління фінансовою стійкістю банку в умовах економічних дисбалансів: монографія. Одеса: ОНЕУ, 2015. 418 с.

5. Колесник О. О. Присутність іноземного капіталу як фактор дестабілізації банківської системи України. Науковий вісник ОНЕУ Всеукрайнська асоціаџія молодих науковців. 2012. № 22(174). C. 67-73.

6. Колесник О. О., Борисова Л. Є. Банківський бізнес в епоху цифрової економіки. Причорноморські економічні студії. 2019. Вип. 47. С. 62-67.

7. Лачкова Л. І., Лалабєкян В. А. Антикризове управління комерційним банком: сутність та критерії ефективності. Економічна стратегія і перспективи розвитку сфери торгівлі та послуг. 2013. Вип. 1(1). С. 144-148. $824 \mathrm{c}$.

8. Лігоненко Л. О. Антикризове управління підприємством: підручник. Київ: КНТЕУ, 2005.

9. Манжос С. Б. Антикризове управління банківською діяльністю: форми і технології. Науковий вісник Херсонського державного університету. Серія Економічні науки. 2014. Вип. 6, ч. 5. С. 16-20.

10. Павловський С. В. Фінансування підприємств в системі антикризового управління: автореферат дис. ... канд. екон. наук: 08.00.08 / Київський національний економічний університет імені Вадима Гетьмана. Київ, 2017. 22 с.

11. Перехрест Л., Бриштіна В. Антикризове управління як чинник підвищення рівня фінансової безпеки банків. Актуальні проблеми економіки. 2010. № 6(108). С. 245-249.

12. Пшик Б. І. Сучасні методи антикризового управління фінансовою діяльністю банку. Ефективна економіка. 2017. № 12. URL: http://www.economy.nayka.com.ua/?op=1\&z=5961.

13. Сирота В. С. Функціональні та інституційні аспекти антикризового менеджменту в банківських установах України: дис. ... канд. екон. наук: 08.00.08 / ДВНЗ «Університет банківської справи». Київ, 2015. 251 с.

14. Тимошенко О. В., Буцька О. Ю., Сафарі Ф. Х. Антикризове управління як передумова підвищення ефективності діяльності підприємства. Економічний аналіз. 2016. Т. 23, № 2. C. $187-192$. 
ФІНАНСОВІ РЕСУРСИ: ПРОБЛЕМИ ФОРМУВАННЯ ТА ВИКОРИСТАННЯ

15. Чуб П. М. Методи антикризового управління банком. Фінанси, облік $i$ аудит. 2011. № 18. C. 211-219.

16. Шишкіна Т. М. Сучасні проблеми антикризового управління у банківській системі. $H a-$ укові праці Кіровоградського національного технічного університету. Економічні науки. 2016. Вип. 29. С. 128-134.

\section{References}

1. Baranovskyi, O. (2009). Antykryzovi zakhody uriadiv i tsentralnykh ban $\neg$ kiv zarubizhnykh krain [Anti-crisis measures of governments and central banks of foreign countries]. Visnyk Natsionalnoho banku Ukrainy - Bulletin of the National Bank of Ukraine, 4, 8-19 [in Ukrainian].

2. Dubyna, M. V. (2018). Mekhanizm rozvytku rynku finansovykh posluh na osnovi formuvannia instytutu doviry: teoriia, metodolohiia, praktyka [The mechanism of the financial services market development based on the formation of the institute of trust: theory, methodology, practice]. Chernihiv: ChNTU [in Ukrainian].

3. Dubyna, M. V., Razghulina, N. O. (2018). Teoretychni aspekty funktsionuvannia systemy bankivskoho ipotechnoho kredytuvannia fizychnykh osib v Ukraini [Theoretical aspects of the functioning of the bank mortgage lending system of individuals in Ukraine]. Problemy i perspektyvy ekonomiky ta upravlinnia - Problems and prospects of economics and management, 4 (16), 176-187 [in Ukrainian].

4. Zvieriakov, M. I., Zvieriakov, A. M. (2015). Antykryzove upravlinnia finansovoiu stiikistiu banku $v$ umovakh ekonomichnykh dysbalansiv [Anti-crisis management of the bank financial stability in the conditions of economic imbalances]. Odesa: ONEU [in Ukrainian].

5. Kolesnyk, O. O. (2012). Prysutnist inozemnoho kapitalu yak faktor destabilizatsii bankivskoi systemy Ukrainy [Presence of foreign capital as a factor of destabilization of the banking system of Ukraine]. Naukovyi visnyk ONEU Vseukrainska asotsiatsiia molodykh naukovtsiv - ONEU Scientific Bulletin All-Ukrainian Association of Young Scientists, 22(174), 67-73 [in Ukrainian].

6. Kolesnyk, O. O., Borysova, L. Ye. (2019). Bankivskyi biznes v epokhu tsyfrovoi ekonomiky [Banking business in the digital economy]. Prychornomorski ekonomichni studii - Black Sea Economic Studies, 47, 62-67 [in Ukrainian].

7. Lachkova, L. I., Lalabiekian, V. A. (2013). Antykryzove upravlinnia komertsiinym bankom: sutnist ta kryterii efektyvnosti [Anti-crisis management of a commercial bank: the nature and criteria of efficiency]. Ekonomichna stratehiia i perspektyvy rozvytku sfery torhivli ta posluh - Economic strategy and prospects for the development of trade and services, 1(1), 144-148 [in Ukrainian].

8. Lihonenko, L. O. (2005). Antykryzove upravlinnia pidpryiemstvom [Anti-crisis management of the enterprise]. Kyiv: KNTEU [in Ukrainian].

9. Manzhos, S. B. (2014). Antykryzove upravlinnia bankivskoiu diialnistiu: formy i tekhnolohii [Anti-crisis management of the banking activity: forms and technologies]. Naukovyi visnyk Khersonskoho derzhavnoho universytetu. Seriia Ekonomichni nauky - Scientific Bulletin of Kherson State University. Series Economic Sciences, 6 (5), 16-20 [in Ukrainian].

10. Pavlovskyi, S. V. (2017). Finansuvannia pidpryiemstv $v$ systemi antykryzovoho upravlinnia [Financing of enterprises in the anti-crisis management system]. (Candidate's thesis). Kyivskyi natsionalnyi ekonomichnyi universytet imeni Vadyma Hetmana, Kyiv [in Ukrainian].

11. Perekhrest, L., Bryshtina, V. (2010). Antykryzove upravlinnia yak chynnyk pidvyshchennia rivnia finansovoi bezpeky bankiv [Anti-crisis management as a factor for the improvement of the financial security of banks]. Aktualni problemy ekonomiky - Current Issues in Economic, 6 (108), 245-249 [in Ukrainian].

12. Pshyk, B. I. (2017). Suchasni metody antykryzovoho upravlinnia finansovoiu diialnistiu banku [Modern methods of the anti-crisis management of the financial activity of the bank]. Efektyvna ekonomika - Efficient economy, 12. Retrieved from http://www.economy.nayka.com.ua/?op=1\&z=5961.

13. Syrota, V. S. (2015). Funktsionalni ta instytutsiini aspekty antykryzovoho menedzhmentu $v$ bankivskykh ustanovakh Ukrainy [Functional and institutional aspects of the anti-crisis management in banking institutions of Ukraine]. (Candidate's thesis). DVNZ «Universytet bankivskoi spravy», Kyiv [in Ukrainian]. 
ФІНАНСОВІ РЕСУРСИ: ПРОБЛЕМИ ФОРМУВАННЯ ТА ВИКОРИСТАННЯ

14. Tymoshenko, O. V., Butska, O. Yu., Safari, F. Kh. (2016). Antykryzove upravlinnia yak peredumova pidvyshchennia efektyvnosti diialnosti pidpryiemstva [Anti-crisis management as a prerequisite for improving the efficiency of the enterprise]. Ekonomichnyi analiz - Economic analysis, 23 (2), 187-192 [in Ukrainian].

15. Chub, P. M. (2011). Metody antykryzovoho upravlinnia bankom [Methods of the anti-crisis management of the bank]. Finansy, oblik $i$ audyt-Finance, accounting and auditing, 18, 211-219 [in Ukrainian].

16. Shyshkina, T. M. (2016). Suchasni problemy antykryzovoho upravlinnia u bankivskii systemi [Modern problems of the anti-crisis management in the banking system]. Naukovi pratsi Kirovohradskoho natsionalnoho tekhnichnoho universytetu. Ekonomichni nauky - Scientific papers of Kirovograd National Technical University. Economic sciences, 29, 128-134 [in Ukrainian].

Мельник Віктор Миколайович - доктор економічних наук, професор, професор кафедри фінансів, ДВНЗ

«Київський національний економічний університет імені Вадима Гетьмана» (просп. Перемоги, 54/1, м. Київ, 03057, Україна).

Мельник Виктор Николаевич - доктор экономических наук, профессор, профессор кафедры финансов, ГВУЗ «Киевский национальный экономический университет имени Вадима Гетьмана» (просп. Победы, 54/1, г. Киев, 03057, Украина).

Melnyk Viktor - Doctor of Economics, Professor, Professor, Department of Finance, State Higher School of Economics, Kyiv National Economic University named after Vadim Hetman (54/1 Peremogy Av., 03057 Kyiv, Ukraine).

E-mail: melnik_viktor@ukr.net

ORCID: https://orcid.org/0000-0002-7439-1564

Колесник Ольга Олексіївна - старший викладач кафедри фінансів, банківської справи та страхування, Одеський національний університет імені I. I. Мечникова (вул. Дворянська, 2, м. Одеса, 65082, Україна).

Колесник Ольга Алексеевна - старший преподаватель кафедры финансов, банковского дела и страхования, Одесский национальный университет имени И. И. Мечникова (ул. Дворянская, 2, г. Одеса, 65082, Украина).

Kolesnik Olga - Senior Lecturer in Finance, Banking and Insurance, Odessa II Mechnikov National University

(2 Dvoryanska Str., 65082 Odesa, Ukraine).

E-mail: kolesnikolgaalekseevna@gmail.com

ORCID: https://orcid.org/0000-0003-4262-157X

Мельник В., Колесник О. Теоретичні аспекти дослідження сутності антикризового менеджменту банківських установ. Проблеми і перспективи економіки та управління. 2019. № 4 (20). С. 334-341. 